\title{
Jurassic-Cretaceous Stratigraphy of Malaysia
}

\author{
Mat Niza Bin Abdul Rahman \\ Technical Services Division, Department of Mineral and Geoscience Malaysia, Ipoh, Perak, Malaysia \\ Email:mniza@jmg.gov.my
}

How to cite this paper: Rahman, M.N.B.A. (2019) Jurassic-Cretaceous Stratigraphy of Malaysia. Open Journal of Geology, 9, 668-670.

https://doi.org/10.4236/ojg.2019.910070

Received: August 17, 2019

Accepted: September 21, 2019

Published: September 24, 2019

Copyright (c) 2019 by author(s) and Scientific Research Publishing Inc. This work is licensed under the Creative Commons Attribution International License (CC BY 4.0).

http://creativecommons.org/licenses/by/4.0/

\begin{abstract}
In Peninsular Malaysia, the Jurassic-Cretaceous sequences are represented by continental deposits in several isolated basins. Generally, the sequences are characterised by the fining upward sequences, comprising reddish brown to red siltstone, sandstone and conglomerate often interpreted as molasse sequences. In Sabah and Sarawak, the Jurassic-Cretaceous sequences are represented by the marine deposits comprising argillaceous, some arenaceous and calcareous rocks and associated chert, lava, and pyroclastics.
\end{abstract}

\section{Keywords}

Jurassic-Cretaceous, Peninsular Malaysia, Continental Deposits, Sabah and Sarawak, Marine Deposits

\section{Introduction}

In Peninsular Malaysia, the Jurassic-Cretaceous sequences are represented by the continental deposits that were deposited in several isolated basins throughout the country. Generally, the sequences are characterised by the fining upward sequences comprising reddish brown to red siltstone, sandstone and conglomerate often interpreted as molasse sequences.

The Jurassic-Cretaceous continental sequences distributed in Peninsular Malaysia are Saiong Formation, Kayu Hitam Formation, Berapit Formation, Tan Hain Formaton, Panau Formation, Koh Formation, Tembeling Group, Gagau Group, Gerek Sandstone, Bertangga Sandstone, Ma'okil Formation, Paloh formation, Lesong Sandstone, Ulu Endau Beds, Tebak Formation and Panti Formation. The sequences are distributed in the Western, Central and Eastern Belts of Peninsular Malaysia. Most of the sequences are exposed in the Central Belt, whilst only the Saiong Formation is exposed in the Western Belt and extends northwardly into southern Thailand. In the Eastern Belts, the Jurassic-Cretaceous sequences are in the southeastern part of the Peninsular. Fossil 
gastropods, bivalves and plants as well as palynomorphs were discovered within those rock units. Dinosaur teeth and footprints were discovered in the Lotong Sandstone of the Gagau Group in Hulu Terengganu. The dinosaur teeth also were reported in the Cretaceous rocks in Pahang.

In Sabah and Sarawak, the Jurassic-Cretaceous sequence is represented by the marine deposits comprising argillaceous, some arenaceous and calcareous rocks, and associated chert, lava, and pyroclastics. Among the Jurassic-Cretaceous sequences in Sabah is the Madai-Baturong Formation, whilst in Sarawak it is represented by the Kedadom Formation, Sejingkat Formation, Pedawan Formation, Serabang Formation, Bau Limestone and Sebangan Hornstone. Most of them are shallow marine shelf deposits except for the chert dominant Sejingkat Formation and part of the Serabang Formation and the Sebangan Hornstone which might be deposited in a deeper marine condition.

\section{Stratigraphy}

The Jurassic-Cretaceous continental sequences distributed in Peninsular Malaysia are shown in Table 1.

In Sabah and Sarawak, the Jurassic-Cretaceous shallow to deep marine deposits are shown in Table 2.

\section{Correlation}

Based on lithological characteristics and fossil contents, the Jurassic-Cretaceous sequences in Peninsular Malaysia have the same relative stratigraphic position but are not necessarily contemporaneous. The Mangking Sandstone of the Tembeling Group is possible to be correlated with the Lotong Sandstone of the Gagau Group. Generally, the other predominantly arenaceous sequences namely the Ulu Endau Beds, Tebak Formation, Panti Formation, Bertangga Sandstone, Koh formation, Lesong Sandstone, Tebak Formation and Gerek Formation are also possible to be correlated with the Mangking Sandstone. The Paloh Formation is partly lateral equivalent of the Ma'Okil Formation [1].

In Sarawak, the upper part of the Kedadom Formation is interfingered with the lower part of the Bau Limestone. The Sejingkat Formation is interfingered with the Serabang Formation and the lower Kedadom Formation and the Bau Limestone. The Pedawan Formation is also laterally equivalent to the Bau Limestone [1].

Table 1. List of the Jurassic-Cretaceous sequences within the Western-Central-Eastern Belts in Peninsular Malaysia.

\begin{tabular}{|c|c|c|c|c|c|}
\hline \multirow{2}{*}{ Age } & \multicolumn{2}{|c|}{ Western Belt } & \multicolumn{3}{|c|}{ Central Belt - Eastern Belt } \\
\hline & \multicolumn{2}{|c|}{ Kedah-Perak } & Kelantan & Pahang-Terengganu & Johor \\
\hline & \multicolumn{2}{|l|}{ Saiong } & & Gagau Group & Paloh Formation \\
\hline Jurassic- & Formation & Berapit Formation & Panau Formation & Tembeling Group & Lesong Sandstone \\
\hline \multirow[t]{2}{*}{ Cretaceous } & Kayu Hitam & Tan Hain Formation & Koh Formation & Gerek Sandstone & Ulu Endau Beds \\
\hline & & & & & Panti Formation \\
\hline
\end{tabular}


Table 2. List of the Jurassic-Cretaceous sequences in Sabah and Sarawak.

\begin{tabular}{|c|c|c|}
\hline Age & Sabah & Sarawak \\
\hline \multirow{6}{*}{ Jurassic-Cretaceous } & \multirow{6}{*}{ Madai-Baturong Formation } & Kedadom Formation \\
\hline & & Sejingkat Formation \\
\hline & & Pedawan Formation \\
\hline & & Serabang Formation \\
\hline & & Bau Limestone \\
\hline & & Sebangan Hornstone \\
\hline
\end{tabular}

\section{Conclusion}

In Peninsular Malaysia, the Jurassic-Cretaceous rocks are mostly of continental deposits, generally reddish in colour with grey varieties in parts. Only the Paloh Formation was deposited in the transition from shallow marine to continental environment. Dinosaur teeth and footprint had been discovered within the Lotong Sandstone of the Gagau Group in Hulu Terengganu. Dinosaur teeth had also been reported in Pahang. Detail study needs to be done on the continental deposits to determine another potential dinosaur site in Malaysia. In Sabah and Sarawak, the Jurassic-Cretaceous sequences were deposited in a shallow to deep marine environment.

\section{Acknowledgements}

This is a contribution to UNESCO-IUGS IGCP Project 679.

\section{Conflicts of Interest}

The author declares no conflicts of interest regarding the publication of this paper.

\section{References}

[1] Lee, C.P., Leman, M.D., Hassan, K., Nasib, B.M. and Karim, R. (2004) Stratigraphic Lexicon of Malaysia. Geological Society of Malaysia, $162 \mathrm{p}$. 